CLINICAL STUDY

\title{
Relationship between free and total 1,25-dihydroxyvitamin $D$ in conditions of modified binding
}

\author{
H J C van Hoof, R G L de Sévaux ${ }^{1}$, H van Baelen ${ }^{2}$, L M J W Swinkels, C Klipping ${ }^{3}$, H A Ross and C G J Sweep \\ Department of Chemical Endocrinology, and ${ }^{1}$ Department of Nephrology, University Hospital Nijmengen, Nijmegen, The Netherlands, ${ }^{2}$ Laboratory for \\ Experimental Medicine, Catholoic University Leuven, Leuven, Belgium and ${ }^{3}$ Dinox Pharmaceutical Research, Nijmegen, The Netherlands
}

(Correspondence should be addressed to R de Sévaux, Department of Nephrology, University Hospital Nijmegen, PO Box 9101, 6500 HB Nijmegen, The Netherlands; Email: R.deSevaux@nefro.azn.nl)

\begin{abstract}
Objective: A novel assay was employed to study the free 1,25-dihydroxyvitamin $\mathrm{D}\left(1,25(\mathrm{OH})_{2} \mathrm{D}\right)$ concentrations in various populations with different levels of $1,25(\mathrm{OH})_{2} \mathrm{D}$ and vitamin $\mathrm{D}$ binding protein (DBP).

Design: In 12 healthy women before and after 3 months of oral estrogen/progestagen treatment, 10 pregnant women, and 16 patients with a nephrotic syndrome and normal renal function, the concentrations of total and free $1,25(\mathrm{OH})_{2} \mathrm{D}$, DBP and albumin were assessed.

Methods: The total concentration of $1,25(\mathrm{OH})_{2} \mathrm{D}$ in serum was assessed using a radioreceptor assay. The free fraction of $1,25(\mathrm{OH})_{2} \mathrm{D}$ was measured using symmetric dialysis. DBP was assessed using single radial immunodiffusion. Serum albumin concentrations were measured on an automated analyzer.

Results: In healthy women, the concentrations of total $1,25(\mathrm{OH})_{2} \mathrm{D}$, free $1,25(\mathrm{OH})_{2} \mathrm{D}$ and DBP were $132 \pm 19 \mathrm{pmol} / \mathrm{l}, 92 \pm 30 \mathrm{fmol} / \mathrm{l}$ and $5.59 \pm 0.43 \mu \mathrm{mol} / \mathrm{l}$. After 3 months of estrogen/progestagen treatment, total $1,25(\mathrm{OH})_{2} \mathrm{D}$ and DBP levels rose significantly to $175 \pm 51 \mathrm{pmol} / \mathrm{l}$ and $8.32 \pm$ $1.59 \mu \mathrm{mol} / \mathrm{l}(P \leq 0.05$ and $P \leq 0.001)$; the free $1,25(\mathrm{OH})_{2} \mathrm{D}$ remained unchanged $(105 \pm$ $39 \mathrm{fmol} / \mathrm{l}$; not significant). Pregnant women had significantly higher levels of total $1,25(\mathrm{OH})_{2} \mathrm{D}$ and DBP $(239 \pm 68 \mathrm{pmol} / \mathrm{l}$ and $11.32 \pm 1.77 \mu \mathrm{mol} / \mathrm{l}$; both $P \leq 0.001)$; the free $1,25(\mathrm{OH})_{2} \mathrm{D}$ level, however, was not different $(104 \pm 27 \mathrm{fmol} / \mathrm{l}$; not significant). Unexpectedly, in patients with nephrotic syndrome, no lower DBP levels were found $(5.36 \pm 0.84 \mu \mathrm{mol} / \mathrm{l})$ relative to that in controls. Despite this, levels of both total $(69 \pm 26 \mathrm{pmol} / \mathrm{l}, P \leq 0.001)$ and free $1,25(\mathrm{OH})_{2} \mathrm{D}(53 \pm$ $28 \mathrm{fmol} / \mathrm{l} ; P \leq 0.001)$ were significantly lower than in controls. Albumin levels were lowered from $628 \pm 38 \mu \mathrm{mol} / \mathrm{l}$ to $300 \pm 84 \mu \mathrm{mol} / \mathrm{l}(P \leq 0.001)$.

Conclusions: Higher estrogen levels result in higher DBP levels, with a parallel rise in total $1,25(\mathrm{OH})_{2} \mathrm{D}$ levels but without a change in the biologically active free fraction. The results in patients with nephrotic syndrome show that, with increasing glomerular protein leakage, the free $1,25(\mathrm{OH})_{2} \mathrm{D}$ concentration cannot be maintained.
\end{abstract}

European Journal of Endocrinology 144 391-396

\section{Introduction}

Vitamin D is an important hormone which is involved in many biological processes. To study the effects of a hormone, it is widely considered best to assess its free concentration instead of the total concentration. This is because, according to the so-called 'free hormone hypothesis', this fraction better reflects the biologically active hormone (1).

All of the vitamin D metabolites that circulate in blood are bound to carrier proteins. The active metabolite, 1,25-dihydroxyvitamin $\mathrm{D} \quad\left(1,25(\mathrm{OH})_{2} \mathrm{D}\right)$, has been shown to bind to a specific binding protein, vitamin D binding globulin (DBP), albumin, and perhaps also to lipoproteins. Whilst the binding of DBP of vitamin D occurs with a $K_{a}$ similar to that for $1,25(\mathrm{OH})_{2} \mathrm{D}(2)$, the other hydroxylated metabolites bind to DBP with affinities that are about 100 times as high (3-5). The metabolites 25-hydroxyvitamin D $(25(\mathrm{OH}) \mathrm{D})$ and 24,25-dihydroxyvitamin D $(24,25$ $\left.(\mathrm{OH})_{2} \mathrm{D}\right)$ circulate in blood at concentrations about 1000 times higher than those of $1,25(\mathrm{OH})_{2} \mathrm{D}$, but because of the remarkably high concentration of DBP in relation to the vitamin $\mathrm{D}$ metabolites, many binding sites are still available for $1,25(\mathrm{OH})_{2} \mathrm{D}$ and the percentage of free hormone is very low $(<0.1 \%)(6)$.

The DBP synthesis takes place in the liver and can be stimulated by estrogens (2). This increased DBP level is 
capable of binding more $1,25(\mathrm{OH})_{2} \mathrm{D}$. However, theoretically there should be no effect on the free concentration, since estrogens have no direct effect on the 1-hydroxylation of $25(\mathrm{OH}) \mathrm{D}$ in the kidney (7). Therefore, when the free-hormone hypothesis also holds for $1,25(\mathrm{OH})_{2} \mathrm{D}$, there should be no signs of hypercalcemia when total $1,25(\mathrm{OH})_{2} \mathrm{D}$ levels are increased during estrogen intake. The opposite would be found in situations of reduced DBP levels, such as with nephrotic syndrome or liver cirrhosis. Reduced levels of total $1,25(\mathrm{OH})_{2} \mathrm{D}$ would be found with normal free concentrations. Literature on this subject, however, is scarce.

Indeed, it has been shown that during pregnancy there is a rise in both DBP and total $1,25(\mathrm{OH})_{2} \mathrm{D}$ due to increased estrogen levels. However, in some studies the free $1,25(\mathrm{OH})_{2} \mathrm{D}$ concentration remained constant $(6$, 8 , 9), while others found increased free levels (10). For nephrotic syndrome, some authors have reported no drop in free $1,25(\mathrm{OH})_{2} \mathrm{D}$ concentrations (11), whereas others found a reduced free index (12).

Reported results during premenopausal estrogen intake are even more diverse. An increase in total $1,25(\mathrm{OH})_{2} \mathrm{D}$ has been found $(8,13,14)$, but also no increase (15). Only two studies investigated the free index and found it to remain constant $(8,13)$. To our knowledge, no study has been performed in which the free concentration has been assessed during premenopausal estrogen intake.

In the study presented here, total and free $1,25(\mathrm{OH})_{2} \mathrm{D}$ concentrations were assessed, as well as albumin and DBP levels in sera of nephrotic syndrome patients and of women during a 3 month study during which they took oral contraceptives. Furthermore, DBP was assessed in samples from pregnant women, for which the total and free $1,25(\mathrm{OH})_{2} \mathrm{D}$ concentrations were presented previously (9). Thus, the behavior of the free $1,25(\mathrm{OH})_{2} \mathrm{D}$ concentration was studied in several situations for which different DBP levels were to be expected.

\section{Subjects and methods}

\section{Subjects}

The control group consisted of samples from 12 healthy women who were not taking any medications known to influence vitamin D or calcium metabolism. As shown before, there is no difference between healthy men and women in terms of total $1,25(\mathrm{OH})_{2} \mathrm{D}(16)$, free $1,25(\mathrm{OH})_{2} \mathrm{D}$ (9) or DBP (17), indicating that the present control group can be used in all further statistical analyses.

Blood samples were also obtained from the aforementioned 12 women after 3 months of oral contraceptive therapy. This therapy consisted of the administration of $20 \mu \mathrm{g}$ ethinylestradiol with either $150 \mu \mathrm{g}$ desogestrel (Mercilon, Organon, Oss, The
Netherlands) or $75 \mu \mathrm{g}$ gestodeen (Harmonet, AHP Pharma, Hoofddorp, The Netherlands).

Furthermore, blood samples were obtained from 10 pregnant women (third trimester) and 16 patients (14 male, 2 female) with nephrotic syndrome and normal renal function. Again, none of these subjects were taking any medications known to influence vitamin D or calcium metabolism.

The study was performed according to the standards of the Ethical Committee of the Academic Hospital Nijmegen, St Radboud, Nijmegen, The Netherlands.

\section{Total 1,25(OH $)_{2} D$ assay}

The assessment of total $1,25(\mathrm{OH})_{2} \mathrm{D}$ was performed as described before. In short, $1 \mathrm{ml}$ serum samples were extracted using $15 \mathrm{ml}$ diethylether, after which the extracts were subjected to paper chromatography, which separates the major vitamin D metabolites. A radioreceptor assay was then performed using calfthymus receptor; it was based on the assay as described by Reinhardt et al. (16). The sensitivity of the assay was $0.5 \mathrm{fmol} /$ tube, corresponding to $4 \mathrm{pmol} / \mathrm{l}$ in serum, calculated as 3 times the standard deviation in the lowest standard point $(0 \mathrm{pmol} / \mathrm{l})$ and reading that from the standard curve. The intra- and interassay coefficients of variation were $10.5 \%(n=15$ at $93.4 \mathrm{pmol} /$ l) and $11.5 \%(n=8$ at $103.3 \mathrm{pmol} / \mathrm{l})$ respectively. The range of values measured in healthy controls was $80-$ $200 \mathrm{pmol} / \mathrm{l}$. There was no significant difference between men and women, nor any correlation with age.

\section{Free 1,25(OH $)_{2} \mathrm{D}$ assay}

The free $1,25(\mathrm{OH})_{2} \mathrm{D}$ concentration was assessed by measuring the free fraction and multiplying it by the total $1,25(\mathrm{OH})_{2} \mathrm{D}$ concentration. The free fraction was measured using symmetric dialysis as described previously (9). In short, before dialysis, the serum samples were diluted 15 -fold in phosphate buffer $(50 \mathrm{mmol} / \mathrm{l}$ phosphate, $0.1 \mathrm{~mol} / \mathrm{l} \mathrm{NaCl}$; $\mathrm{pH} 7.40$ ). At this dilution, the free fraction is such that about $20-30 \%$ of the tracer migrates through the membrane during dialysis for approximately $16 \mathrm{~h}$. To assess the free fraction, one compartment of a dialysis cell (Dianorm $\mathrm{GmbH}$, Munich, Germany) was filled with $1 \mathrm{ml}$ of this diluted serum and the other compartment was filled with the same diluted sample to which $0.15 \mathrm{KBq}$ ${ }^{3} \mathrm{H}-1,25(\mathrm{OH})_{2} \mathrm{D}_{3} \quad(23.8 \mathrm{fmol}) \quad(\mathrm{NET} \quad 626, \quad 6.3 \mathrm{TBq} /$ mmol; NEN, Dupont de Nemours, The Netherlands) had been added. The amount of tracer added (23.8 fmol) corresponds to $347 \mathrm{pmol} / \mathrm{l}$ in undiluted plasma, which is of the order of magnitude of the endogenous total $1,25(\mathrm{OH})_{2} \mathrm{D}$ concentration. The rate at which the tracer migrated from one compartment to the other was directly proportional to the magnitude of the free fraction of hormone. The free fraction was 
determined by comparing the dialysis rate of the sample with that of the tracer in a reference preparation for which the free fraction was known. This reference preparation was a $1 \%$ human serum albumin (HSA) (OHRA 20/21, Behringwerke AG, Marburg, Germany) solution in phosphate buffer $(50 \mathrm{mmol} / \mathrm{l}$ phosphate, $0.1 \mathrm{~mol} / \mathrm{l} \mathrm{NaCl}$; $\mathrm{pH} 7.40$ ) for which the free concentration had been assessed beforehand using indirect equilibrium dialysis. The range of values measured in healthy controls was 60-150 fmol/l.

\section{Other assays}

Calcium, albumin, creatinine and total protein were kindly assessed in the Central Clinical Chemistry Laboratory of the Academic Hospital Nijmegen, using a Hitachi 747 automated analyzer (Boehringer Mannheim Corp., Indianapolis, IN, USA). In nephrotic syndrome, calcium levels were corrected for the low albumin levels by the formula: $\mathrm{Ca}_{\text {corrected }}=\mathrm{Ca}_{\text {assessed }}-$ 0.025 albumin $+1.00 \mathrm{mmol} / \mathrm{l}$.

DBP levels were kindly assessed in the Laboratory for Experimental Medicine of Professor Dr R Bouillon at the Catholic University Leuven, Belgium, using single radial immunodiffusion (17).

$25(\mathrm{OH}) \mathrm{D}$ was assessed using HPLC according to Dabek et al. (18).

Intact parathyroid hormone (PTH) was measured using a commercial assay (Nichols, San Juan Capistrano, CA, USA).

\section{Statistics}

All values are given as means \pm s.D. Statistical analysis was performed using SPSS for Windows (version $6 \cdot 0 \cdot 1$; SPSS Inc., USA). When Shapiro-Wilks testing revealed that data were not normally distributed, logarithmic transformation was performed. To compare groups, ANOVA and subsequent $t$-tests were performed. Correlation analysis was done by calculating the Pearson correlation coefficients.

\section{Results}

Ranges and significant differences for total and free $1,25(\mathrm{OH})_{2} \mathrm{D}$ as well DBP are shown in Fig. 1 .

During the use of oral contraceptives, DBP levels rose from $5.59 \pm 0.43 \mu \mathrm{mol} / \mathrm{l}$ to $8.32 \pm 1.59 \mu \mathrm{mol} / \mathrm{l}(P \leq$ $0.001)$. The mean total $1,25(\mathrm{OH})_{2} \mathrm{D}$ concentration rose significantly from baseline levels of $132.4 \pm$ $19.1 \mathrm{pmol} / \mathrm{l}$ to $174.9 \pm 50.8 \mathrm{pmol} / \mathrm{l}$ after 3 months of therapy $(P \leq 0.05)$. The mean free $1,25(\mathrm{OH})_{2} \mathrm{D}$ concentrations at both points did not differ significantly and were $92.3 \pm 29.9 \mathrm{fmol} / \mathrm{l}$ and $105.2 \pm 39.5 \mathrm{fmol} / \mathrm{l}$ respectively. Albumin levels showed no significant change (from $628 \pm 38 \mu \mathrm{mol} / \mathrm{l}$ at baseline to $623 \pm$ $43 \mu \mathrm{mol} / \mathrm{l}$ after 3 months).
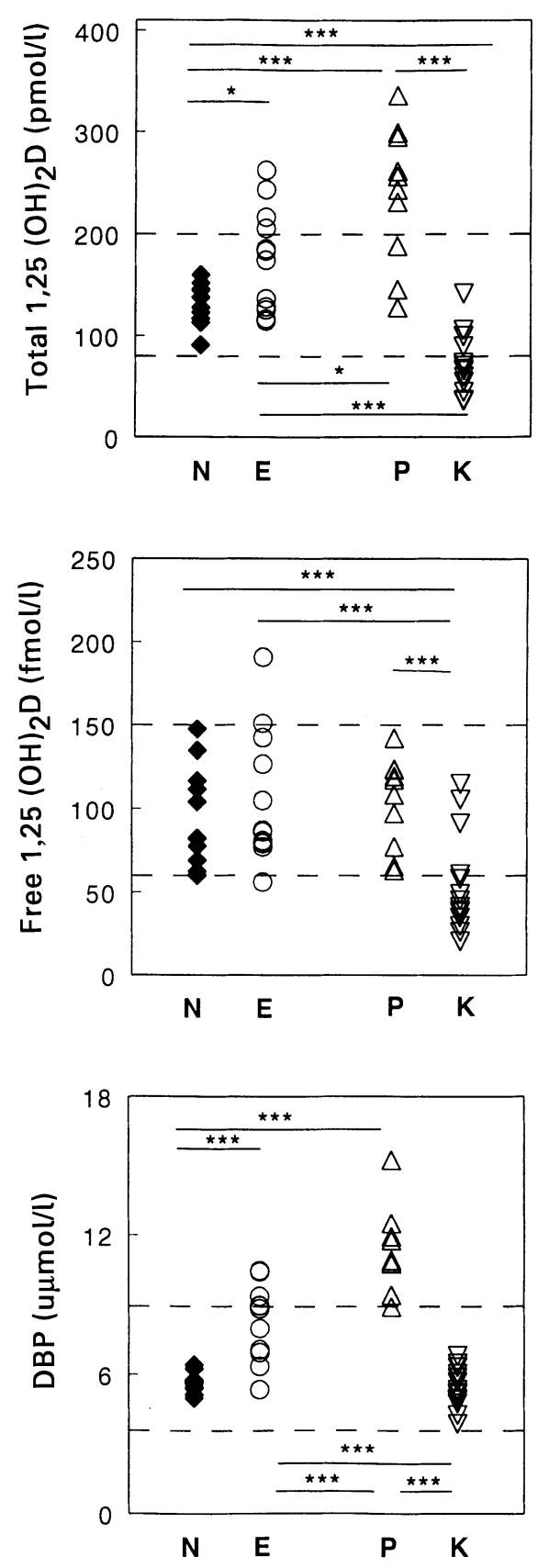

Fig. 1 Total $1,25(\mathrm{OH})_{2} \mathrm{D}$, free $1,25(\mathrm{OH})_{2} \mathrm{D}$ and $\mathrm{DBP}$ concentrations in normal women before $(\mathrm{N}, \bullet)$ and after 3 months of estrogen/ progestagen intake $(E, O)$, in pregnant women $(P, \Delta)$ and in patients with nephrotic syndrome $(K, \nabla)$. The dotted lines indicate reference ranges $\left({ }^{\star} P<0.05,{ }^{\star \star \star} P<0.001\right)$.

In pregnant women, a significant increase was found in DBP $(11.32 \pm 1.76 \mu \mathrm{mol} / \mathrm{l}, P \leq 0.001)$ and total $1,25(\mathrm{OH})_{2} \mathrm{D} \quad(239.1 \pm 67.5 \mathrm{pmol} / \mathrm{l}, \quad P \leq 0.001)$, but not in free $1,25(\mathrm{OH})_{2} \mathrm{D}(103.8 \pm 27.0 \mathrm{fmol} / \mathrm{l})$.

The characteristics of the patients with nephrotic syndrome are summarized in Table 1. In nephrotic 
Table 1 Characteristics of patients with nephrotic syndrome ( $n=$ 16; 14 male, 2 female).

\begin{tabular}{lcc}
\hline Characteristic & $\begin{array}{c}\text { Mean value } \\
\pm \text { s.D. }\end{array}$ & $\begin{array}{c}\text { Reference } \\
\text { value }\end{array}$ \\
\hline Age (years) & $44.5 \pm 17.1$ & \\
Serum DBP $(\mu \mathrm{mol} / \mathrm{l})$ & $5.35 \pm 0.84$ & $3.57-8.93$ \\
Serum creatinine $(\mu \mathrm{mol} / \mathrm{l})$ & $96.8 \pm 25.5$ & $50-110$ \\
Serum albumin $(\mu \mathrm{mol} / \mathrm{l})$ & $300 \pm 84$ & $536-768$ \\
Serum $25(\mathrm{OH}) \mathrm{D}^{\mathrm{a}}(\mathrm{nmol} / \mathrm{l})$ & $29.8 \pm 11.3$ & $25-97.5$ \\
Urine protein $(\mathrm{g} / 24 \mathrm{~h})$ & $10.5 \pm 3.2$ & $<0.1$ \\
Creatinine clearance $(\mathrm{ml} / \mathrm{min})$ & $119 \pm 35$ & $70-110$ \\
Calcium $(\mathrm{mmol} / \mathrm{l})_{\text {PTH }^{\mathrm{b}}(\mathrm{pmol} / \mathrm{l})}^{2.5 \pm 0.1}$ & $2.2-2.6$ \\
& $3.8 \pm 1.7$ & $<6.5$
\end{tabular}

a $n=14$.

b $n=7$.

syndrome, the mean DBP level was $5.35 \pm$ $0.84 \mu \mathrm{mol} / \mathrm{l}$, a value that was not different from the controls. The mean total $1,25(\mathrm{OH})_{2} \mathrm{D}$ concentration was $68.7 \pm 25.7 \mathrm{pmol} / \mathrm{l}$ and the mean free concentration was $53.3 \pm 27.9 \mathrm{fmol} / \mathrm{l}$. The total $1,25(\mathrm{OH})_{2} \mathrm{D}$ concentration in these patients was significantly lower than the reference level $(P \leq 0.001)$, as was the free concentration $(P \leq 0.001)$. The albumin concentration was significantly lower than that in the controls $(300 \pm 84 \mu \mathrm{mol} / \mathrm{l}$ vs $628 \pm 38 \mu \mathrm{mol} / \mathrm{l} ; P \leq 0.001$. In patients with nephrotic syndrome, statistically significant positive correlations were found between the concentration of albumin and the levels of both total $1,25(\mathrm{OH})_{2} \mathrm{D}(r=0.54 ; P \leq 0.05)$ and free $1,25(\mathrm{OH})_{2} \mathrm{D}$ $(r=0.52 ; P \leq 0.05)$. DBP levels did not correlate with $1,25(\mathrm{OH})_{2} \mathrm{D}$, or with albumin. The levels of $25(\mathrm{OH}) \mathrm{D}$ were low $(29.8 \pm 11.3 \mathrm{mmol} / \mathrm{l})$ and correlated with DBP $(r=0.55 ; P \leq 0.05)$ and urine protein $(r=$ $-0.57 ; \quad P \leq 0.05)$, but not with total or free $1,25(\mathrm{OH})_{2} \mathrm{D}$ or with albumin levels.

\section{Discussion}

To our knowledge, this is the first report of the measurement of the free $1,25(\mathrm{OH})_{2} \mathrm{D}$ concentration during premenopausal estrogen/progestagen intake. There have been previous studies investigating the effect of premenopausal estrogen/progestagen on the concentrations of total $1,25(\mathrm{OH})_{2} \mathrm{D}$ and $\mathrm{DBP}$, but these results were ambiguous. An increase in total $1,25(\mathrm{OH})_{2} \mathrm{D}(13,14)$ has been reported, though others found no such effect (15). Most, but not all (14), studies report an increase in the concentration of DBP $(2,13)$. Two studies report no change in the free $1,25(\mathrm{OH})_{2} \mathrm{D}$ index during oral estrogen intake $(8$, 13), but the actual free concentration was not assessed. This index is the molar ratio of the total concentration of $1,25(\mathrm{OH})_{2} \mathrm{D}$ to the concentration of DBP, and obviously is not as precise as a real measurement since it ignores changes in the albu$\mathrm{min} / \mathrm{DBP}$ ratio and interference from high levels of
$25(\mathrm{OH})_{2} \mathrm{D}$. The present study shows a significant increase in both total $1,25(\mathrm{OH})_{2} \mathrm{D}$ and DBP levels, whilst the free $1,25(\mathrm{OH})_{2} \mathrm{D}$ concentrations remain nearly constant. Similar results were found in pregnancy, during which the increase in both total $1,25(\mathrm{OH})_{2} \mathrm{D}$ and DBP levels is even higher than that after 3 months of estrogen use, but the free concentration also remains nearly the same. This increase in total $1,25(\mathrm{OH})_{2} \mathrm{D}$ and DBP concentrations during pregnancy has been reported previously $(2,8)$. Reports on the free $1,25(\mathrm{OH})_{2} \mathrm{D}$ are again equivocal. Some authors have reported an increase in the free $1,25(\mathrm{OH})_{2} \mathrm{D}$ concentration (10), whereas others have found no change in the free $1,25(\mathrm{OH})_{2} \mathrm{D}$ index $(6,8)$.

These results show that the free hormone hypothesis is valid for $1,25(\mathrm{OH})_{2} \mathrm{D}$, as it is for thyroid hormones and the other steroid hormones (19), and therefore suggest that the free concentration of $1,25(\mathrm{OH})_{2} \mathrm{D}$ is a more reliable marker for the biological availability of $1,25(\mathrm{OH})_{2} \mathrm{D}$ than is the total plasma concentration. It is also shown that premenopausal higher estrogen levels do not result in increased levels of free $1,25(\mathrm{OH})_{2} \mathrm{D}$. Any additional effects of the progestagenic compound during the experiments are not known.

In patients with nephrotic syndrome, many plasma proteins are lost in the urine. As a consequence, it was expected that lower levels of DBP would be found in parallel with lower total $1,25(\mathrm{OH})_{2} \mathrm{D}$ levels, and that, because of normocalcemic conditions, the free $1,25(\mathrm{OH})_{2} \mathrm{D}$ concentrations would be normal. However, the results were not as expected. Although most patients had profound hypoalbuminemia, the DBP levels were normal, and total $1,25(\mathrm{OH})_{2} \mathrm{D}$ concentrations as well as free $1,25(\mathrm{OH})_{2} \mathrm{D}$ levels were reduced. The data in the literature on changes in the DBP and total $1,25(\mathrm{OH})_{2} \mathrm{D}$ in nephrotic syndrome are equivocal. Some authors report lower concentrations of DBP (2, $20,21)$, and in some studies a correlation between serum albumin and DBP levels was found $(12,21)$. In contrast, other investigators report unchanged levels of DBP in patients with nephrotic syndrome (22). Likewise, total $1,25(\mathrm{OH})_{2} \mathrm{D}$ levels have been found to have decreased $(12,21,23,24)$ or to have been unchanged $(22,25)$ in patients with nephrotic syndrome.

A few investigators have used different methods to measure free serum $1,25(\mathrm{OH})_{2} \mathrm{D}$ levels in patients with nephrotic syndrome. In one study, free levels of $1,25(\mathrm{OH})_{2} \mathrm{D}$, as determined by assessing the free index, were found low (12). However, with the same methodology, Chan et al. (26) and Grymonprez et al. (21) reported normal levels. Koenig et al., who used centrifugal ultrafiltration, also found normal levels of free $1,25(\mathrm{OH})_{2} \mathrm{D}(11)$. It has been shown, however, that the centrifugal ultrafiltration method for assessing the free $1,25(\mathrm{OH})_{2} \mathrm{D}$ concentration is rather prone to disturbance, especially at low concentrations (9). The validity of the assessment of the free index is questionable, since it neglects relevant variables $(9,10)$. 
The lower levels of total $1,25(\mathrm{OH})_{2} \mathrm{D}$ found in the present study could be the result of the lower steady state, resulting from the increased loss of $1,25(\mathrm{OH})_{2} \mathrm{D}$ in the urine. This would also result in lower free $1,25(\mathrm{OH})_{2} \mathrm{D}$ concentrations. However, one would expect increased synthesis of $1,25(\mathrm{OH})_{2} \mathrm{D}$ after prolonged lower free $1,25(\mathrm{OH})_{2} \mathrm{D}$ levels, because of reduced intestinal calcium uptake and consequent changes in calcium metabolism. The fact that, nonetheless, lower free $1,25(\mathrm{OH})_{2} \mathrm{D}$ levels were found in patients with nephrotic syndrome indicates, therefore, that there is a problem with the $1,25(\mathrm{OH})_{2} \mathrm{D}$ synthesis. This problem was previously attributed to lowered concentrations of $25(\mathrm{OH})_{2} \mathrm{D}$ in patients with nephrotic syndrome, because of the loss in the urine of $25(\mathrm{OH})_{2} \mathrm{D}$ bound to binding proteins $(12,27)$. Indeed, total 25(OH)D levels were also reduced in the present study, and negatively correlated with urinary protein loss. Another strong argument for this theory is the finding that $25(\mathrm{OH}) \mathrm{D}$ replacement therapy raises not only $25(\mathrm{OH})_{2} \mathrm{D}$ levels but also total $1,25(\mathrm{OH})_{2} \mathrm{D}$ levels $(28)$. This would make a decrease in $25(\mathrm{OH})_{2} \mathrm{D}$ levels a likely explanation for the reduced free $1,25(\mathrm{OH})_{2} \mathrm{D}$ levels.

Another explanation for the reduced $1,25(\mathrm{OH})_{2} \mathrm{D}$ levels could be impairment of $1 \alpha$-hydroxylase activity and a blunted response to PTH because of defective proximal tubular function (27). These possible mechanisms are the subject of further research.

Furthermore, a correlation of $1,25(\mathrm{OH})_{2} \mathrm{D}$ with serum albumin (and not with serum DBP) was observed in this study, as well as in previous research (24). At first sight, this seems incomprehensible, because under normal circumstances at least $85 \%$ of all $1,25(\mathrm{OH})_{2} \mathrm{D}$ is bound to DBP (29). However, this phenomenon could be explained by the continuous loss of albumin-bound $1,25(\mathrm{OH})_{2} \mathrm{D}$ in the urine. Lower total $1,25(\mathrm{OH})_{2} \mathrm{D}$ levels will lead to lower free $1,25(\mathrm{OH})_{2} \mathrm{D}$ levels and, consequently, to a dissociation of the DBPbound fraction. This reasoning assumes that the loss of albumin-bound $1,25(\mathrm{OH})_{2} \mathrm{D}$ is much larger than the loss of DBP-bound $1,25(\mathrm{OH})_{2} \mathrm{D}$. Although not much is known about DBP concentrations in nephrotic syndrome, there is indeed some evidence, reported by Schmidt-Gayk et al. (20), for this assumption.

In conclusion, it has been shown that in premenopausal women with endogenous or exogenous estrogen/progestagen excess the serum free $1,25(\mathrm{OH})_{2} \mathrm{D}$ concentration is constant and independent of DBP or total $1,25(\mathrm{OH})_{2} \mathrm{D}$ concentrations. This means that the free hormone hypothesis can be applied to $1,25(\mathrm{OH})_{2} \mathrm{D}$ as for other steroid hormones.

In patients with nephrotic syndrome, however, free $1,25(\mathrm{OH})_{2} \mathrm{D}$ concentrations are low despite normal levels of DBP. These alterations in $1,25(\mathrm{OH})_{2} \mathrm{D}$ metabolism may be responsible for the reported alterations in bone metabolism in patients with nephrotic syndrome (30).

\section{References}

1 Ekins R. Measurement of free hormones in blood. Endocrine Reviews 19901 5-46.

2 Haddad JG \& Walgate J. Radioimmunoassay of the binding protein for vitamin D and its metabolites in human serum. Concentrations in normal subjects and patients with disorders of mineral homeostasis. Journal of Clinical Investigation $1976 \mathbf{5 8}$ 1217-1222.

3 Haddad JG \& Walgate J. 25 Hydroxy vitamin D transport in human plasma. Isolation and partial characterization of the calcifediol binding protein. Journal of Biological Chemistry 1976 251 4803-4809.

4 Bouillon R, van Baelen H, Rombauts W \& de Moor P. The purification and characterisation of the human-serum binding protein for the 25-hydroxycholecalciferol (transcalciferin). Identity with group-specific component. European Journal of Biochemistry 197666 285-291.

5 Haddad JG, Min C, Mendelsohn M, Slatopolsky E \& Hahn TJ. Competitive protein binding radioassay of 24,25 dihydroxyvitamin D in sera from normal and anephric subjects. Archives of Biochemistry and Biophysics $1977 \mathbf{1 8 2}$ 390-395.

6 Vieth R. Simple method for determining specific binding capacity of vitamin D binding protein and its use to calculate the concentration of 'free' 1,25 dihydroxyvitamin D. Clinical Chemistry $1994 \mathbf{4 0} 435-441$.

7 Henry HL. $25(\mathrm{OH}) \mathrm{D}_{3}$ metabolism in kidney cell cultures: lack of a direct effect of estradiol. American Journal of Physiology $1981 \mathbf{2 4 0}$ E119-E124.

8 Bouillon R, van Assche FA, van Baelen H, Heyns W \& de Moor P. Influence of the vitamin D binding protein on the serum concentration of 1,25 dihydroxyvitamin $\mathrm{D}_{3}$. Journal of Clinical Investigation 198167 589-596.

9 van Hoof HJC, Swinkels LMJW, Ross HA, Sweep CGJ \& Benraad TJ. Determination of non-protein-bound plasma 1,25-dihydroxyvitamin D by symmetric (rate) dialysis. Analytical Biochemistry 1998258 176-183.

10 Bikle DD, Gee E, Halloran B \& Haddad JG. Free 1,25 dihydroxyvitamin D levels in serum from normal subjects, pregnant subjects, and subjects with liver disease. Journal of Clinical Investigation $1984 \mathbf{7 4} 1966-1971$.

11 Koenig KG, Lindberg JS, Zerwekh JE, Padalino PK, Cushner HM \& Copley JB. Free and total 1,25 dihydroxyvitamin D levels in subjects with renal disease. Kidney International $1992 \mathbf{4 1} 161-165$.

12 Auwerx J, de Keyser L, Bouillon R \& de Moor P. Decreased free 1,25 dihydroxycholecalciferol index in patients with the nephrotic syndrome. Nephron 198642 231-235.

13 Aarskog D, Aksnes L, Markestad T \& Rodland O. Effect of estrogen on vitamin D metabolism in tall girls. Journal of Clinical Endocrinology and Metabolism 1983 57 1155-1158.

14 Buchanan JR, Santen R, Cauffman S, Cavaliere A, Greer RB \& Demers LM. The effect of endogenous estrogen fluctuation on metabolism of 25 hydroxyvitamin D. Calcified Tissue International 198639 139-144.

15 Zofkova I \& Kancheva RL. Effect of estrogen status on bone regulating hormones. Bone $199619227-232$.

16 van Hoof HJC, Swinkels LMJW, van Stevenhagen JJ, van den Berg H, Ross HA \& Benraad TJ. Advantages of paper chromatography as a preparative step in the assay of 1,25-dihydroxyvitamin D. Journal of Chromatography 1993621 33-39.

17 Bouillon R, van Baelen H \& de Moor P. The measurement of the vitamin D binding protein in human serum. Journal of Clinical Endocrinology $1977 \mathbf{4 5} 225-231$.

18 Dabek JT, Harkonen M, Wahlroos O \& Adlercreutz H. Assay for plasma 25-hydroxyvitamin $\mathrm{D}_{2}$ and 25-hydroxyvitamin $\mathrm{D}_{3}$ by high performance liquid chromatography. Clinical Chemistry 198127 1346-1351.

19 Swinkels LMJW, Ross HA \& Benraad TJ. A symmetric dialysis method for the determination of free testosterone in human plasma. Clinica Chimica Acta $1987165341-349$. 
20 Schmidt-Gayk H, Grawunder C, Tschoppe W, Schmitt W, Ritz E, Pietsch $\mathrm{V}$ et al. 25-Hydroxy-vitamin D in nephrotic syndrome. Lancet 19772 105-108.

21 Grymonprez A, Proesmans W, van Dyck M, Jans I, Goos G \& Bouillon R. Vitamin D metabolites in childhood nephrotic syndrome. Pediatric Nephrology 19959 278-281.

22 Huang JP, Bai KM \& Wang BL. Vitamin D and calcium metabolism in children with nephrotic syndrome of normal renal function. Chinese Medical Journal, English 1992105 828832.

23 Goldstein DA, Haldimann B, Sherman D, Norman AW \& Massry SG. Vitamin D metabolites and calcium metabolism in patients with nephrotic syndrome and normal renal function. Journal of Clinical Endocrinology and Metabolism $198152116-$ 121.

24 Lambert PW, de Oreo PB, Fu IY, Kaetzel DM, von Ahn K, Hollis BW et al. Urinary and plasma vitamin $\mathrm{D}_{3}$ metabolites in the nephrotic syndrome. Metabolic Bone Disease and Related Research $198247-15$.

25 Korkor A, Schwartz J, Bergfeld M, Teitelbaum S, Avioli L, Klahr S et al. Absence of metabolic bone disease in adult patients with the nephrotic syndrome and normal renal function. Journal of Clinical Endocrinology and Metabolism 198356 496-500.
26 Chan YL, Mason RS, Parmentier M, Savdie E, Lissner D \& Posen S. Vitamin D metabolism in nephrotic rats. Kidney International 198324 336-341.

27 Mizokuchi M, Kubota M, Tomino Y \& Koide H. Possible mechanism of impaired calcium and vitamin D metabolism in nephrotic rats. Kidney International 199242 335-340.

28 Haldimann B \& Trechsel U. Vitamin D replacement therapy in patients with the nephrotic syndrome. Mineral and Electrolyte Metabolism 19839 154-156.

29 Bikle DD, Siiteri PH, Ryzen E \& Haddad JG. Serum protein binding of 1,25 dihydroxyvitamin $\mathrm{D}$ : a reevaluation by direct measurement of free metabolite levels. Journal of Clinical Endocrinology and Metabolism 198561 969-975.

30 Malluche HH, Goldstein DA \& Massry SG. Osteomalacia and hyperparathyroid bone disease in patients with nephrotic syndrome. Journal of Clinical Investigation 197963 494-500.

Received 16 June 2000

Accepted 6 December 2000 